\title{
RESEARCH ON THE ACCESSIBILITY TO HEALTH AND EDUCATIONAL SERVICES IN THE RURAL AREAS OF EXTREMADURA
}

\author{
Ana Nieto Masot ${ }^{1}$, Gema Cárdenas Alonso²
}

Received 12 July 2014; Accepted 25 February 2015

\begin{abstract}
As the competent laws on Health and Education of the Extremaduran Government read, all the Extremaduran people have the right to their benefits, irrespective of their social, economic and cultural characteristics. Nevertheless, in the Region of Extremadura there are still differences between the rural and urban areas, so, studying how the Extremaduran people can access, with the same conditions, to those services considered basic, such as health and education, is very significant. Using techniques as Network Analyst and the interpolation method IDW, we can note that in Extremadura there are still zones with a very-far- from- laws reality, rural areas with a difficult access to the named services and equipment due to the location on low developed in population and economy areas, and very far from the main communication roads.
\end{abstract}

Keywords: Accessibility, health equipment, educational equipment, Network Analyst, IDW.

\section{Introduction}

Extremadura has some economic, territorial and population characteristics that have conditioned it to be involved in an important socio-economic delay regarding the other Spanish and European regions, despite of showing a priceless historical, natural and cultural legacy. The region has with a little over 1 million inhabitants, a population density of 27 per $\mathrm{km}^{2}$, long distances between one end to the other and a dependent on the agricultural sector economy; this means $10 \%$ of the regional employment and $8 \%$ of Gross Value Added (Nieto and Gurría, 2008).

Within the Extremadura site itself, there are also territorial differences, rural areas trying to decrease the inequalities respecting the urban ones, in which the economic activity, employment, equipment and services are concentrated, and so the majority of the population of Extremadura.

The urban areas are located in the most productive agricultural zones, on the sedimentary banks, taking advantage of irrigation and rain fed farming such as vine and olive (Gurría, 2007),

\footnotetext{
1 Professor Ana Nieto Masot, Department of Arts and Territory Sciences, University of Extremadura, Plaza de Caldereros, 10074 Cáceres; ananieto@unex.es

${ }^{2}$ Gema Cárdenas Alonso, researcher, Department of Arts and Territory Sciences, University of Extremadura, Plaza de Caldereros, 10074 Cáceres; gemacardenas@unex.es
} 
as well as they are the best communicated zones in the region around the main communication roads. Opposite the rural areas, located in a surrounding, isolated and less accessible border with a population density in some cases, below 10 per $\mathrm{km}^{2}$, in which people have no served services regarding life quality and social welfare and move to those urban or better developed and populated county headers, in order to find better socioeconomic opportunities and see their needs of basic equipment, such as health and education services.

Something cannot be ignored. Some areas of the region have headers centrally (main towns) located on the communication roads that enjoy the different services and services, due to the administrative decentralization of Spanish autonomies, and which provide the surrounding towns and villages with the necessary services for people's welfare: from health to educational, judicial, administrative services, etc. This can be considered as a sustainable way to provide equipment and services to the Extremaduran population. Nevertheless, the inside imbalances are still present and, in order to solve them, the fact of supporting the social justice (Gutiérrez et al, 2000) and equity when possible is necessary avoiding the economic aspects.

Having into account that $39.3 \%$ of the population in Extremadura is located in villages of less than 2,000 inhabitants, as the Padron 2013 , as well as that $50.92 \%$ of the total is concentrated in 371 municipalities, all of them of less than 10,000 inhabitants, it is a very important point to know how the rural population of Extremadura get to the equipment considered as basic: the health and the educational ones.

From the point of view of the health services study, the Community of Extremadura is ruled by the Health Law of Extremadura 10/2011, June 28, whose main objective is to adjust so much as possible the territorial organization to the need of an effective Health System which makes, the equity in access to these services, possible for all. In the same way the Educational law of Extremadura 4/2011, March 7, guarantees the right to an equal access to the Educational System to all the people from Extremadura regardless their personal, social, economic or cultural circumstances. Due to this, the importance of a good distribution of health and educational equipment in our region which guarantees the best accessibility to them, is important. To check this fact, the need of the current study becomes absolutely necessary.

At a health level, Extremadura is structured in two territorial levels: Health Areas and Health Zones. The first ones mean the basic health division, where most of the reference hospitals of our region are located. The second ones form the territorial and population frame of the General Practice. These two divisions have been designed regarding geographic, demographic, socioeconomic, employment, epidemiological and cultural factors and the proximity to the already existing communication roads. Nowadays, the region has 8 Health Areas and 113 Health Zones whose territorial distribution is not homogeneous due to the large land and the high population dispersion with small and little populated areas as Coria and Navalmoral de la Mata and others large such as Caceres or with more population such as Badajoz and Mérida. Regarding the Health Zones there are also some differences. In the most populated municipalities, Cáceres and Badajoz, there are several Zones. On the other hand, less populated municipalities as Barcarrota or Montijo have to be integrated in the same zone, in order to provide the citizens with the basic services in a sustainable way. Within these divisions, we have 16 hospitals, 110 Health Centres and 417 local offices. The hospitals are located in the most populated towns of the region. The Health Centres and the local offices reach the smallest municipalities (Figure 1). 


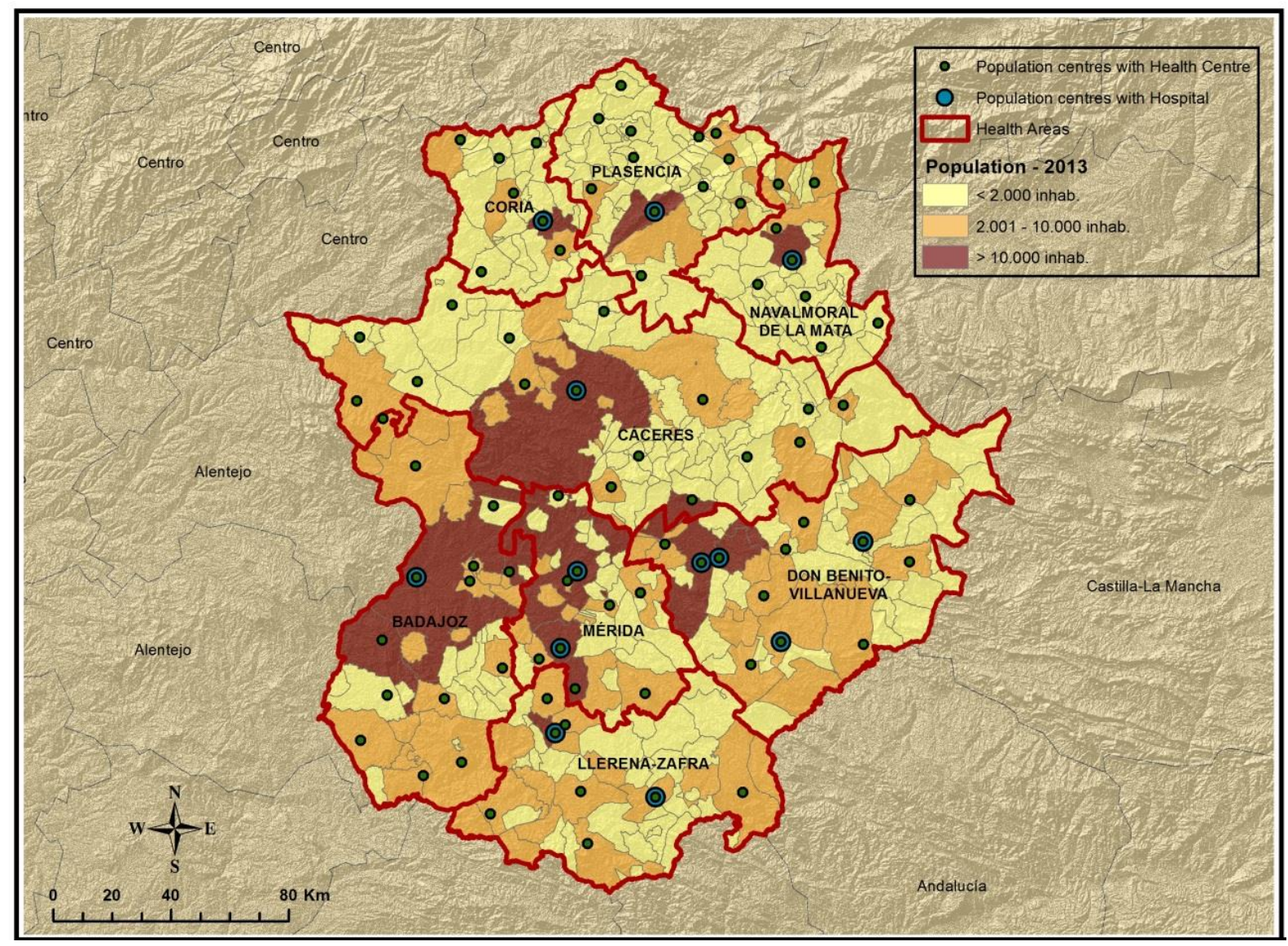

Fig 1. Location of health equipment and population of Extremadura, 2013. Source: Prepared by the author based on I.N.E. (Statistics National Institute and Regional Ministry of Health and Social Policy of the Government of Extremadura data.

At an educational level (Law 4/2011, March 7, of Education in Extremadura), the territorial planning of the school network in Extremadura, is made by the Regional Administration so, having into account the citizens' proximity, a structured organization is established. This division is called Educational Districts which are groups of neighbour municipalities belonging to the same natural region, to the same functional areas or due to other social or economic factors. Each educational district must provide some basic services which guarantee quality schooling, from Pre-primary, Primary and Secondary Schools until adult education centres, Teachers and resources, Professional Music Conservatory, School of Languages and the three modalities of Baccalaureate, always paying attention to the demographic characteristics and the social demand of services. Due to the dispersion of people in Extremadura, the rural areas have been the main concern in planning educational divisions. So have formed Grouped Rural Schools as a unique centre where students from nearby small towns are grouped and they can study in equal opportunities and respecting conditions similar education quality to students in the larger municipalities (Figure 2). 


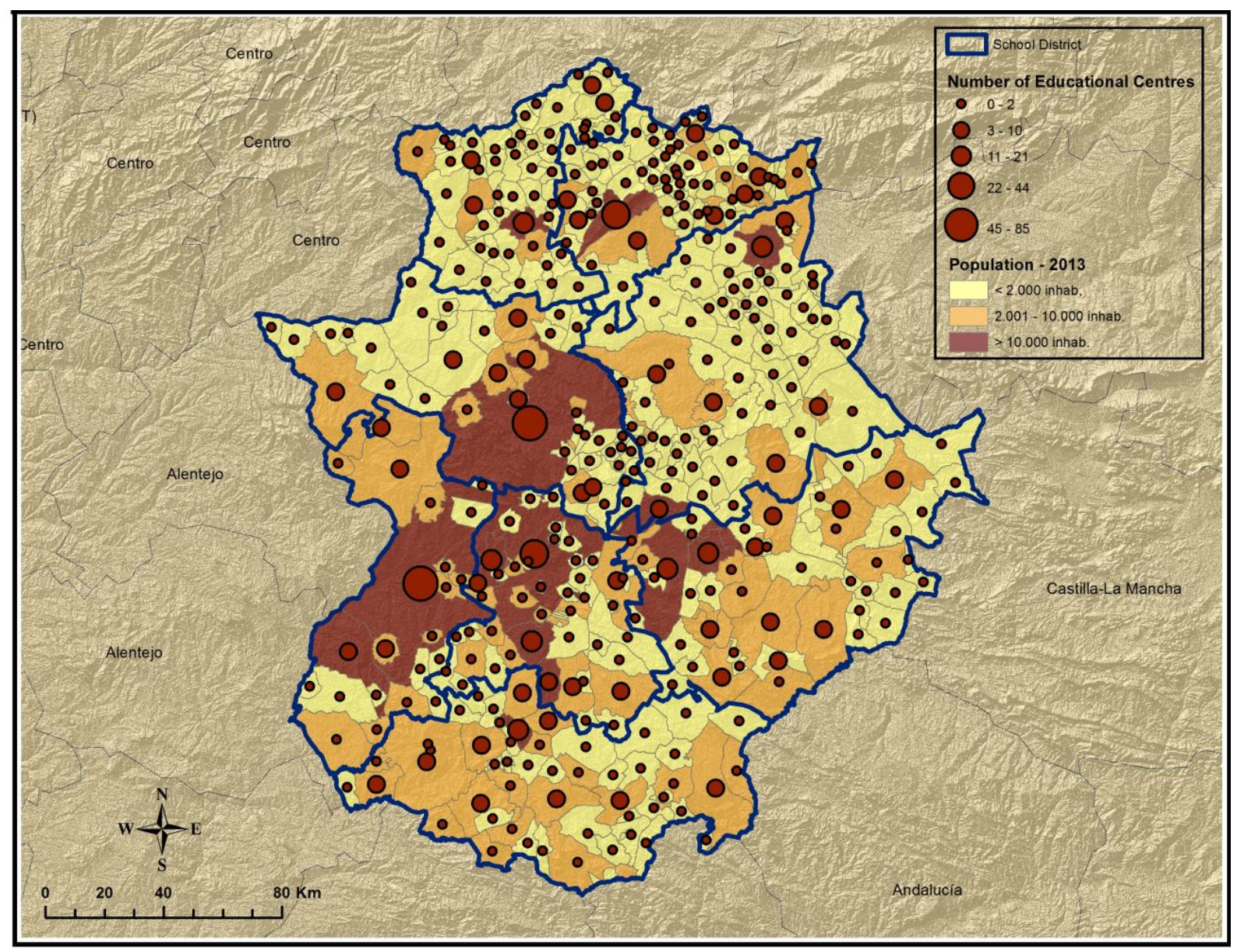

Fig 2. Location of Educational Equipment and Population of Extremadura, in 2013. Source: Prepared by the author based on I.N.E. (Statistics National Institute) and Regional Ministry of Health and Social Policy of the Government of Extremadura data.

We also have to study the communications system as it is essential in the territory integration and in the exchange between rural and urban centres and the access to this educational and health equipment (Gurría and Nieto, 2003). The region of Extremadura is based mainly on the Road Network which has been widely developed during the democratic period (1986 - 2013) not only in quality but also in quantity. The railway transport is suffering a step backwards and the air transportation has only a token presence. There are two main roads that vertebrate the Road Network of Extremadura: the Autovia de la Plata which lays from the North to the South and it has been very important in the regional development as it has communicated Extremadura with the North and the South of Spain and, the Highway A-5, that crosses the region from the Northeast to the West, communicating Madrid with Lisbon. The main Extremaduran towns, Badajoz, Cáceres, Mérida and Plasencia, are the best communicated by being located on these roads, with a transport structure with fair development, complexity and cohesion. In most of cases, the towns which are the best at production, salaries, employment and population are those that are located near these roads, for example, some irrigation zones or Tierra de Barros, vine and olives zones. On the other hand, there are several zones in the North and in the East of Badajoz, where are very remote villages, with poor communications which result to be no favoured in productive inversions, equipment and services location and consequently, in the concentration of inhabitants.

The road Network of Extremadura (Figure 3) is a simple net, nothing complex, with a bad distribution and hierarchy, with a poor development and joint which produces an increase of distance-cost-time, higher costs in the transport, increase in goods prices difficulty to get investors, etc. (Nieto and Cárdenas, 2015). Higher inversions are compulsory for these less developed rural zones and it can enable higher incidence on the diversification of activities and employment and the best possible accessibility to the basic equipments and services. 


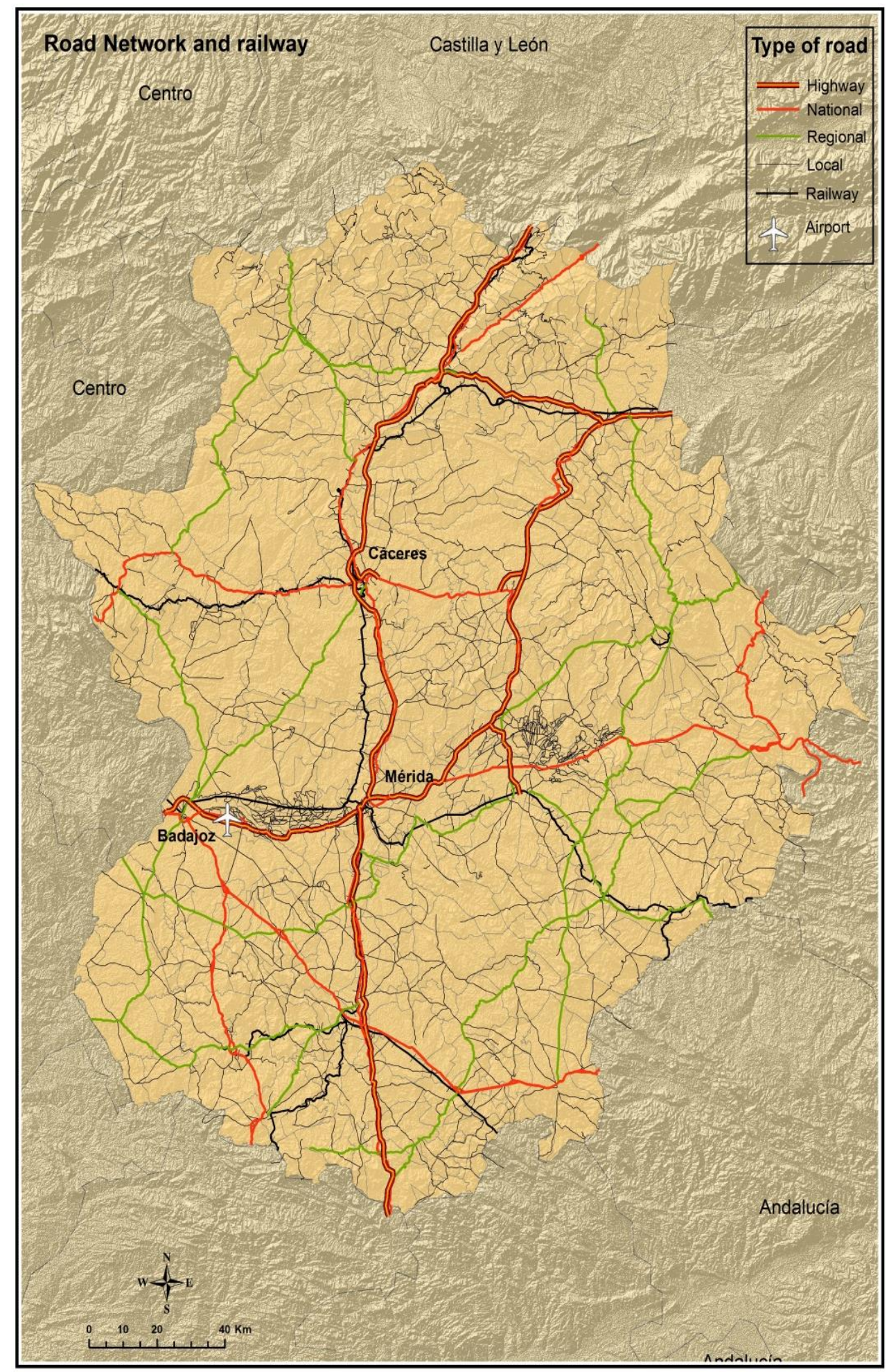

Fig 3. Road Network of Extremadura. Source: Prepared by the author based on BCN 1:200.000 of the National Geographic Institute.

Researching if the population have the same opportunities and conditions in the access to the considered as basic equipment and services, response to the current competent rules, is very interesting. To perform this, a Geographic Information System is used based on the Road Network of Extremadura and on the territory distribution on one hand of the population, and on the other hand of the educational and health equipment and services.

We want to check whether the educational and health facilities are located correctly in Extremadura and how far this location is related to municipalities with largest population and the transport system. 
This type of study is necessary because the positive results in the quality of education of a group of people is largely due to the existence of a good accessibility to educational services, or the evolution of a disease may also depend on the degree of accessibility health resources (Belasco,. et al, 2014).

Rural areas have a lower demographic, social and economic development than urban areas and this makes it difficult to properly access the resources that are analyzed in this study. There are researches that evaluate the quality of health care of the elderly (De Araujo, et al, 2014).

Moreover, there are also studies that use similar methods to those presented in this paper. These are about the zoning of emergency medical services using GIS to predict travel time by ambulance and take into account distribution conditions of the population and traffic in northeast England (McMeekin,. et al, 2014).

\section{Methodology}

In order to study the accessibility of rural areas to health and educational services and equipment in Extremadura, object of this study, a Network Analysis has been carried out, using a Geographic Information System, the software ArcGIS 10.2 which offers a lot of applications for this analysis (Bosque, et al, 2012).

Previously, several basic methods have been necessary, as the cartographic elaboration of the communication roads in the region, as well as the location of health and educational resources in the municipalities of Extremadura. The communication roads and the municipalities of Extremadura have been got from the BCN 1:200,000 of the National Geographic Institute and from the alphanumeric database with the different health and educational resources from the Regional Ministries competent in this matter. These health and educational resources have been matched to a point layers which will coincide with the centroid of the population in each municipality. In fact, a point layers that represents the cores where the different services are located, and a lineal layers with the communication roads of the region.

In this paper we have calculated the accessibility, represented in minutes, from all the municipalities in the region to which have, first, to the health resources (health centres and hospitals) and on the other hand, to the education services ( Primary Education, Secondary Education and Higher Education ( Faculties)). Regarding the Secondary Education, all the centres are included, those which offer the compulsory secondary courses (I.E.S.O) and those which offer also higher studies (I.E.S). The I.E.S. centres offer not only the compulsory secondary studies, also baccalaureate and vocational training. The first are aimed to university education and the others to labour integration and updating, with the objective of increasing and adjusting the knowledge and skills of these future workers.

The accessibility has been calculated from the Extension ArcGIS Network Analyst which allows us to solve the common network problems as for instance, the best route inside a town, finding a way to the next emergency place, identifying a service area around a certain place and so on. Among the group of tools offered, Closest Facilities is the best to calculate the minimum time to get access from one point to another, from one of 385 municipalities of Extremadura to the ones which have different Educational and Health services. This is an application which measures the cost of travelling between origins and destinations and explains which are closer. It shows the best routes and calculates the travel costs, in our case, in minutes.

The result of using the tool Closest Facility is a route brand which offers the time that each core in Extremadura spend to get all the points with health centres, hospitals, faculties, etc., on the net. This information is processed as a data base in order to know the minimum access time spent from each point. For the cartographic representation we have used the interpolation method IDW (Index Distance Weigh), an interpolation method that matches values with the locations, based on the surrounding average values and on specific mathematic formulas which show the smoothness of the resulting surface (Bosque, et al., 1994). The variable cartographically represented decreases its influence when increasing the distance from its location, in other words, when interpolating the surface with the information on the location of educational or health equipment, its furthest location will have less influence, due to the people 
will more probably and logically access to the closest and less time consuming travel places or at the contrary, the closer to the estimated centre of the cell a point is, the highest influence or weight on the average calculation will have (Watson y Philip, 1985). The formula on the weighted reverse distance is known as "Shepard Method" (Shepard, 1968), which equation is as follows:

$$
F(x, y)=\sum_{i=1}^{n} w_{i} f_{i}
$$

where $n$ is the number of dispersion dots in the whole, $f_{\mathrm{i}}$ is the value of the different settled functions among the dispersion dots and $w_{i}$ are the weighting functions ascribed to each dispersion dot. The weight formula:

$$
w_{i}=\frac{h_{i}^{-p}}{\sum_{j-1}^{n} h_{j}^{-p}}
$$

where $p$ is a real, positive and random number called power parameter (usually $\mathrm{p}=2$ ) and $h_{i}$ is the distance from the dispersion dot to the interpolation dot or

$$
h_{i}=\sqrt{\left(x-x_{i}\right)^{2}}+\left(y-y_{i}\right)^{2}
$$

where $(x, y)$ are the coordinates for the interpolation dot and $\left(x_{i}, y_{i}\right)$ are the dispersion

coordinates. The weight changes from the value one on the dispersion dot, to a value near zero when the distance increases the dispersion dot. The weight functions are standardized by means of adding the weights to the unit.

The effect of the weight function is that the surface interpolates each of the dispersion dots and has higher influence among the dispersion dots by the nearest dots when being interpolated.

For a better interpretation of the existing reality in our region concerning the accessibility of the cores to the health and educational services, the results in this paper have been completed with the variable of the population in Extremadura, 2013.Then the population can be studied depending on the resources used in the established time.

\section{Results}

The Public services that produce more population movement between the rural and urban world are those connected to administrative, health and education processes. They are more concentrated in the most important towns in Extremadura, which are well connected to the rest of the territory, They are more concentrated in the most important towns in Extremadura, which are well connected to the rest of the territory, but there are still marginal areas far from major cities and less accessible by road to all health and education services. The basic services as the health centres and the primary schools are well distributed by the whole territory of Extremadura and it is difficult to find a capital of municipality without these services.

We have considered that the optimum time of access to the Health services (Figure 4) is always less than 15 minutes (Rodríguez, 2010), therefore nearly everybody in Extremadura (97.5\% of the population) has good accessibility to the General Practise offered by the health centres because they are included in that range, with the exception of a few municipalities from the East of the region. The results are not the same when the attention is more specialised because the hospitals are located in the big towns of Extremadura and in the most populated region headers where an important amount of population is located. The $64 \%$ of the population of Extremadura has access to the main hospitals in less than 15 minutes, in less than 30 minutes, the $90.6 \%$, and we still can find people, the $9.4 \%$ of the population from bordering areas, who can access to the services between 30 or 60 minutes. These are sparsely populated areas, with good access to the General Practise and we cannot ignore that although their needs of specialized attention are not satisfied, most of them can reach a hospital in less than 30 minutes. 


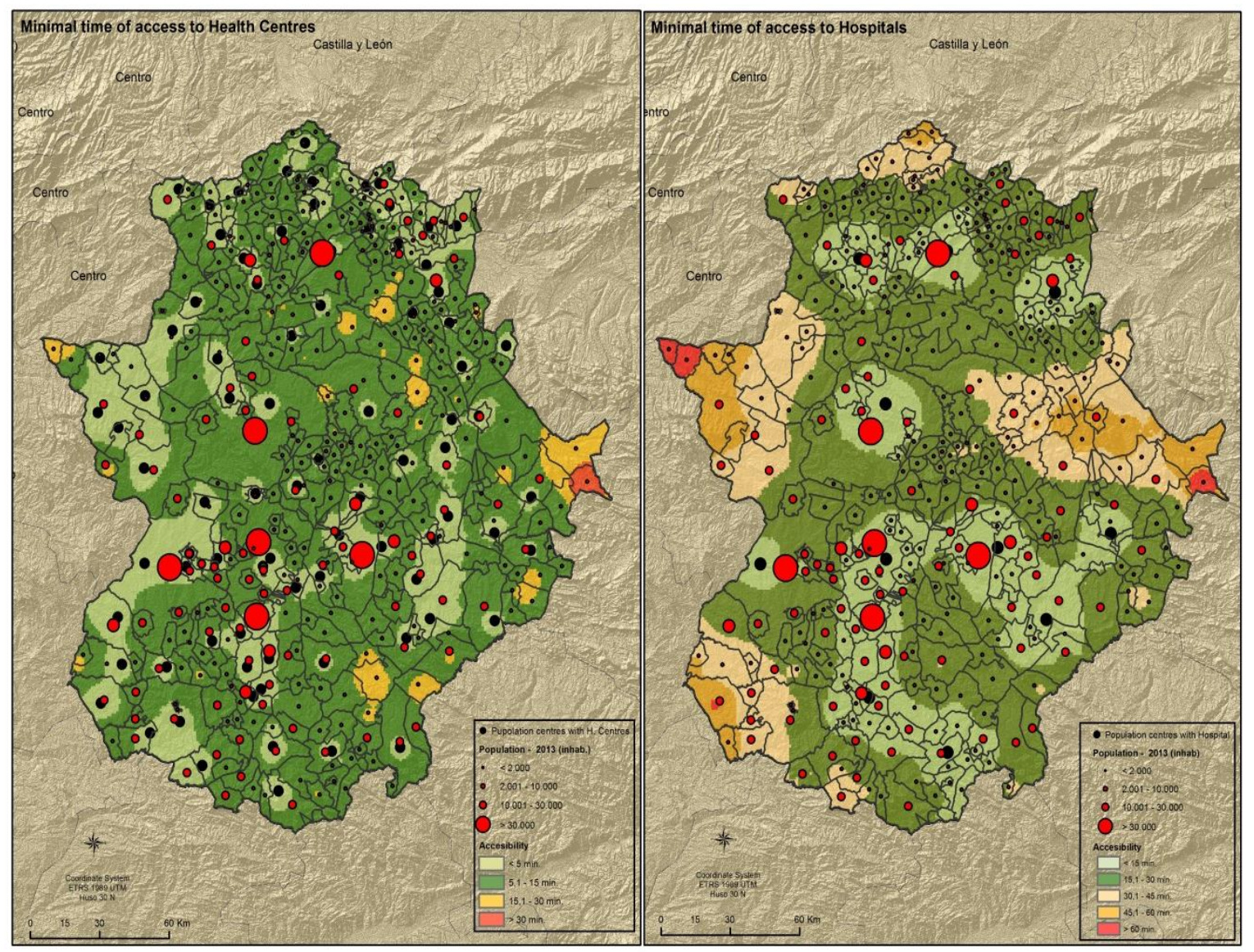

Fig 4. Accessibility to Health services and equipment in Extremadura. Source: By the author by means of data from the regional Ministry of Health and Social Policy of the government of Extremadura.

With regard to the educational services (Figure 5) the accessibility to Primary Education is relatively optimum as $97.6 \%$ of the population can access to it in less than 10 minutes, this can mean that the municipality itself can offer this service without travelling the population. There are smaller places without these services, on the bordering areas with less population as well as in the peneplain of Trujillo-Caceres, with few students willing to study primary studies who have to travel to the grouped rural schools, daily, due to the state of the communication roads, using between 15 and 30 minutes (1.05\%). There are only four municipalities in Extremadura located in the outlying zones in the North and West of the region that can access the primary schools in more than 30 minutes. These are $0.9 \%$ of the total population of Extremadura.

The secondary schools are concentrated in the main population cores and in some geographically marginal cores that have enough population requiring this service. Around fifteen minutes is the average time spent by students coming from less developed areas, either demographically or economically. In peneplain and mountain zones, $96 \%$ is reached and more than 30 minutes in the border places $(0.25 \%)$.

The University Education is located in Badajoz, Cáceres, Mérida, Plasencia and Almendralejo and the furthest places can be reached in a maximum of 3 hours. The best accessibility is less than 15 minutes from the surrounding zones of the towns mentioned above $(42.2 \%$ of the population), at the same time these places are the best situated on the communication system by the Via de la Plata. The $4.7 \%$ of the population spend 60 minutes to get to universities and they are located in the the North and West of Caceres and the East of Badajoz, with more than 2 hour-rides.

The most populated municipalities are the most accessible to the whole system of basic services and which have better accessibility to the transport system. Opposite, the less populated and outlying municipalities, far from any of the big communication roads show less 
access to Health and Educational services. These also show a low population density so they cannot reach a minimum urban category (most with less than 2,000 inhabitants).

In Extremadura another problem on the administrative zones due to rigidity of the administrative boundaries in the delimitation of Health or Educational areas.

A lot of municipalities are located in border of these areas and they are the subject of this matter. These municipalities belong to either Educational or Health zones where the most specialized resources are at more than half an hour drive. If the access of these municipalities to hospitals or secondary schools were more flexible, getting to the nearest ones, although they did not belong to them, they would enjoy the same opportunities than the rest of the population of Extremadura. This is the case of La Roca de la Sierra or Montijo, in the Health Area of Badajoz, with a header hospital in Badajoz, $40 \mathrm{~km}$ far, while the hospital of Merida is less than $30 \mathrm{~km}$ far. Jerez de los Caballeros, Oliva de la Frontera and Salvatierra de los Barros in the southwest of the region also belong to the Health Area of Badajoz, $60 \mathrm{~km}$ far from their header hospital, while in Zafra, to $30 \mathrm{~km}$ far, there is another hospital. In the case of province of Cáceres there is Alia, which belongs to Caceres area, over $100 \mathrm{~km}$ far from its hospital while Talarrubias also has a hospital located in the area of Don Benito-Villanueva.

In Spain there are constitutional principles that ensure equal access to education and health services to all citizens. This is done, in many cases, considering the number of people and other factors such as population density, the accessibility and the proximity to the transport system.

We cannot organize in the same way the education and health services in a city (intensive space) as in a large region such as Extremadura which has almost 400 municipalities.

In regions such as Madrid and Catalonia nine out of 10 people are within 10 minutes from the main hospital, while in Extremadura is around $40-50 \%$ of the population. This shows that the analysis of these resources and finding solutions are needed (Morrillo et al, 2008).

\section{Conclusions}

Studying the physical environment, we can conclude that there are important differences in Extremadura. These characteristics are connected to the socioeconomic and demographic territory development where they happen (Nieto and Gurría, 2010). On one hand the urban areas, the best developed areas in the region due to the agricultural productivity and the best communicated and accessible by the main communication roads in the region. In them, most of the regional population is concentrated as well as the employment and services. On the other hand, the rural areas in the border, which have a scarce population density (in some cases below 10 per $\mathrm{km}^{2}$ ), a very little diversified economic activity and difficulties to access the basic services for instance health and education.

The Education and Health Laws in the region are aimed to ease the equal access to the services by all the people from Extremadura. They try to articulate in a functional and sustainable way, the group of activities, services and benefits. Nevertheless the access to these facilities considered basic in order to get a better life quality not only in the urban but in the rural places, is not as equal as desired, because the territory distribution has been made according to the population concentration, the economic activity, as well as the state of the communication system.

Thanks to the use of SIG techniques with ArcGIS Network Analyst and the tool Closest Facility the cost of travels in minutes have been calculated from 385 municipalities of Extremadura to the main population cores which are equipped with service of primary, secondary, university education (faculties), health centres and hospitals, interpolating the results through a technique of Inverse Distance Weight (IDW). The results show how the most accessible to the basic services municipalities are those with more population and those from the neighbouring areas, while the less populated and outlying, far from the main communication roads are the least accessible to the educational and health services.

The number of inhabitants who belongs to the worst accessibility ranges is not very high calculated by checking the time closest ranges but we cannot forget that this is due to the fact 
that those municipalities with the worst accessibility have a few inhabitants, which does not justify that a lot of places as those from areas of Sierra de San Pedro, La Siberia and Villuercas cannot access these services in less than 50 minutes.

The territorial distribution of Educational and Health facilities is sustainable regarding the population in the case of the majority of the population in Extremadura. Its design is quite optimum but as the concerning laws read, the distribution should be improved in some isolated areas as all the people from Extremadura, regardless their economic, cultural and social situation have the right to some basic quality services with the same opportunities.

We propose three possible ways of improvement in order to solve the shortages on these more isolated places:

- To create new centres, better located, in more marginal areas.

- To introduce new and better communication roads which ease the access from the mountain municipalities, from the East of Badajoz and from the Portuguese borderline which are dispersed in the territory.

- Finally, a greater flexibility in the territory's borders is necessary as well as a new version in the health areas and educational districts too, although the people of some areas have access to schools or hospitals despite not belonging to the border with the territory.

\section{References}

[1] Autonomous Community of Extremadura. Law 10/2001, dated June 28, on Health in Extremadura, BOE $n^{\circ}$. 177, July 25, 2001, pp. 27021 to 27039.

[2] Autonomous Community of Extremadura. Law 4/2011, March 7, of Education in Extremadura, DOE $n^{\circ}$. 47, March 9 2011, pp. 5952 to 6035 and BOE no. 70 March 23, 2011, pp 30994 to 31060.

[3] Belasco, E. J., Gong, G., Pence, B. \& Wilkes, E. (2014). The impact of rural health care accessibility on cancer-related behaviors and outcomes. Applied Health Economics and Health Policy, 12(4), 461-470. Doi: 10.1007/s40258-014-0099-4.

[4] Bosque Sendra, J. (1994). Sistemas de Información Geográfica: Madrid: RA-MA.

[5] Bosque Sendra, J., Moreno Jiménez, A., Fuenzalida Díaz, M. \& Gómez Delgado, M. (2012). Sistemas de Información Geográfica y Localización óptima de Instalaciones y Equipamientos. Madrid: RA-MA.

[6] De Araujo, L., Gama, Z., do Nascimento, F., de Oiveira, H., de Azevedo, W. \& de Almeida, $\mathrm{H}$. (2014). Evaluation of the quality of primary health care from the perspective of the elderly. Ciencia \& Saude coletiva, 19(8), 3521-3532. Doi: 10.1590/141381232014198.21862013.

[7] Gurría Gascón, J. L. (2007). El sistema urbano en Extremadura y su influencia en el desarrollo rural. En Ciudad y Territorio, Estudios Territoriales, XXXIX (151). Madrid: Ministerio de Vivienda.

[8] Gutiérrez Puebla, J., Cristóbal Pinto, C. \& Gómez Cerdá, G. (2000). Accesibilidad peatonal a la red de metro de Madrid: efectos del Plan de Ampliación 1995-99. Anales de Geografía de la Universidad Complutense, 20, 451-464.

[9] McMeekin, P., Gray, J., Ford, G., Duckett, J. \& Price, C. I. (2014). A comparison of actual versus predicted emergency ambulance journey times using generic Geographic Information System software. Emergency Medicine Journal, 31(9), 758-762. Doi: 10.1136/emermed-2012-202246. 
[10] Morrillo, J., Regino, L., Sánchez, M. \& Vega, J. A. (2008). Equidad en la prestación de servicios públicos fundamentales en España: balances de la accesibilidad en educación y sanidad. Badajoz: Servicio de Publicaciones de la Universidad de Extremadura.

[11] Nieto Masot, A., Cárdenas Alonso, G. (2015). El Método Leader como política de desarrollo rural en Extremadura en los últimos 20 años (1991-2013). Boletín de la Asociación de Geógrafos Españoles, $n^{\circ} 69$, in press.

[12] Nieto Masot, A. \& Gurría Gascón, J. L. (2008). Las políticas rurales europeas y su impacto en Extremadura. Boletín de la Asociación de Geógrafos Españoles 48, 225-246.

[13] Nieto Masot, A., Gurría Gascón, J. L. (2010). El modelo rural y el impacto de los programas LEADER y PRODER en Extremadura (Propuesta metodológica). Scripta Nova. Revista Electrónica de Geografía y Ciencias Sociales. 14(340).

[14] Rodríguez Díaz, V. (2011). "Medición de la accesibilidad geográfica de la población a los Hospitales de Alta Resolución de Andalucía mediante herramientas SIG basadas en el análisis de redes". GeoFocus Revista Internacional de Ciencia y Tecnología de la Información Geográfica. (11) 265-292.

[15] Shepard, D. (1968). A two-dimensional interpolation function for irregularly-spaced data (pp. 517-524). In Blue, R. B., Rosenberg, A. M., eds., Proceedings of the 1968 ACM National Conference. Doi: 10.1145/800186.810616.

[16] Watson, D. F. \& Philip, G. M. (1985). Refinement of Inverse Distance Weighted Interpolation (pp. 315-327). In Geo-processing 2. 